\title{
Technology, Surveillance and the Pandemic
}

Chawang Dorjey is an MPhil candidate at Department of Sociology, University of Hyderabad.

The basic aim of the state is maintenance and preservation of it as an entity, and the relation it shares with its subjects is the one similar to that of the shepherd and his herd, leading and protecting its subjects, but it also implies that the subjects follow the rules and regulations meant for them. Each period had a unique system of governance, till the seventeenth century pre-modern society was based on an archaic system, followed by modern system based on the penal system. ${ }^{1}$ Significantly, revolutions in the domain of technology helped the state re-define its system of governance to be unique from its predecessors. The political feature of the post-eighteenth-century society was based on the general strategy of power generated through the medium of discipline, subsequently creating a huge gap that was situated between the state and its subjects, erasing the friction between them - failing to do so the state would face resistance from the lower half of the spectrum, leading to the perils of state. The idea of ruling and regulating over the individuals and the mechanisms on how it functioned has been the same, only the field of application has changed.

Computer technology and with its application into the militaristic, scientific, social and economic spheres, internet connectivity as a byproduct is the epitome of advancements for calculating complex scientific mathematics/algorithms. Militaristically, it helped in the production of a network of spy satellites and sophisticated weapons that functioned on artificial intelligence. The invention of smart-phone technology since then penetrated into the multiple spheres of the society. In the economic sphere, the establishment of a digitalized world gave birth to a new economic space based on the capitalistic ideology, led to the creation

${ }^{1}$ Michele Foucault, Security, Territory, Population, Lectures at the College de France, trans. by Graham Burchell, (New York: Palgrave Macmillan 2009),21-22. 


\section{2 / Chawang Dorjey}

Salesian Journal of Humanities and Social Sciences, Vol. XI, No.1 (May 2020)

ISSN: 0976-1861 |DOI: 10.51818/SJHSS.11.2020.91-95| Page: 91-95,

Section: Articles

of many business firms like Microsoft, Apple, and IBM that were the pioneers of computer technology, followed by Google, Facebook, and Amazon. With the advancement of technology and as a result of the new system of capitalism, it did not only bring in positive effects but also a series of implications to individual life. The artificial intelligence was programmed on the idea of analysing an individual's behavioural pattern, to facilitate an individual's preference in buying products, as we browse through the product on the internet. ${ }^{2}$ The data system created a whole new domain of knowledge, an individual's data is collected into the severs by these firms and stored by them - knowing everything an individual does - which ranged from browsing the internet to which pub he/she visits, whom he/she talks to or as Shoshanna Zuboff argues, "you give us more information about you, about your friends and we can improve the quality of our searches, we don't need you to type at all we know where you are where you have been, we know more or less what you are thinking about."3

The modern state brought this method of monitoring individuals into its apparatus, inducted into the military and police. The state started developing programs to monitor individuals without their knowledge through various digital appliances, invalidating the ideals of liberalism, the grounds on which the modern state was based. That created a hierarchy of power between the state and its subjects, the aim was to maintain social control and remain discreet as much as it could. This particular method was given a tag of intelligence and security of the state, and invoked as a nullifier to external and internal threats. The Edward Snowden case is the best example of the state apparatus spying on its subjects disregarding an individual's privacy, numerous programs have been developed where a person sitting anywhere in the world could be mining out data of any individual sitting elsewhere.

Panopticon structures were enclosed structures like a prison, school, libraries, mental asylums were built in such a manner where the

2 Shoshanna Zuboff, The Age of Surveillance Capitalism, (New York: Public Affairs, 2019), 259.

${ }^{3}$ Ibid, 311. 
authority had a gaze on the movement of an individual, basically used as a corrective measure on criminals, children studying in schools. ${ }^{4}$ The subject observed always had a consciousness of someone having a constant gaze on him/her, nullifying the individuality and hence transforming an individual to a subject of the state. The basic principle behind this structure was to discipline people and by disciplining them was to have an extreme authority on them. The modern way of surveillance functions with this very principle but it works in the name of security. Security and discipline are two elements needed for the proper functioning of a state, these two are different from each other, if we can look at them as an object with two layers, discipline would be below security which forms the base where security sits on-without disciplining an individual; a state cannot ensure its security. The idea that the modern states have incorporated the subjects into the politics of governing, it is true and evident with history that a state needs to follow mechanism such as these to survive whereby it would be pertinent to discipline its subjects the way it wants-as it creates a make-believe scenario for its subjects in-order to normalize certain ideas that a state wants to implement.

The implementation of these mechanisms of discipline and security by the state has been incorporated during the times of epidemics, as a mode of control over the population became corollary to the successful control of epidemic diseases. Whenever such scenarios came up especially in the eighteenth century and enhanced regulations and restrictions that would lead to minimal mobility of the people, this act of regulating were enforced through the army and the police. Further, the state enforced certain sanitary reforms in the area. Strictly following the policy of obedience and order, to stop the epidemics spreading further, the whole area would go into quarantine and every household would be cleaned thoroughly by the personnel responsible for the sanitization. ${ }^{5}$ In these scenarios an individual would be subject to a coerced form

\footnotetext{
${ }^{4}$ Michele Foucault, Discipline and Punish: The Birth of the Prison, trans. by Alan Sheridan, (New York :Vintage books. 1995),200-228.

${ }^{5}$ Ibid, 195-197.
} 


\section{4 / Chawang Dorjey}

Salesian Journal of Humanities and Social Sciences, Vol. XI, No.1 (May 2020)

ISSN: 0976-1861 |DOI: 10.51818/SJHSS.11.2020.91-95| Page: 91-95,

Section: Articles

of discipline by the state, the area under quarantine would be under constant surveillance by the state authorities, to stop the movement of the people their homes used to be locked from outside, structures like the bell tower built in the middle of the town used to function as a mode of looking into the movement of the people and the ones who did not comply to the norms set out by the state during the period of a pandemic would be charged criminally and incarcerated.

Along with this mode of control in the case of epidemics, establishment of prisons, lunatic asylums, leper houses to contain criminals, vagabonds, madmen and lepers are some of the forms of control. ${ }^{6}$ This system spread all over Europe and was adopted everywhere as an efficient measure to discipline the individual, these establishments needed personnel for its functioning hence the institution of policing came into existence. ${ }^{7}$ The existence of police brought in laws fixing a punishment for the deviant who breaks it, creating a binary on what is to be permitted and what is to be stopped. Since then police as a state apparatus crystallized its place in the society making itself an important part of the state apparatus.

The modern state has also practiced the same methods of containing a pandemic that was used in the eighteenth century but it is now backed with technology. As we know that with the rise of computer technology, the state uses this technology to look into an individual, the surveillance during a pandemic has shifted from a person standing on top of a bell tower to someone sitting in an office in front of their computer system or a person using a smart device. During a pandemic, to contain the population and discipline it, police has been using methods such as surveying different locations with the use of drones, using CCTV cameras in certain spaces, these have become the new instruments of panopticon inducing into an individual-a state of conscious and permanent visibility that ensures an automatic functioning of power and since the people know that they are being watched they tend to act in the directives proposed by the state. Hence, the state ensures

${ }^{6}$ Michele Foucault, Madness and Civilisation A History of Insanity in the Age of Reason, trans. by Richard Howard, (New York: Vintage Books, 1988),3-37.

${ }^{7}$ Michele Foucault, Security, Territory, Population, 407-422. 
that there is a minimal movement among the people and the people are isolated from each other so that the disease doesn't spread, as we know that the state has been tracking people through their mobile phones and computers. Applications have been created for the people to know, the risk locations and individuals so that they can be cautious with their surroundings and in turn also letting the state know about their whereabouts. Instruments of panopticon used by the modern state ensure the disciplining of the population, modulating the behaviour of the individuals to make them obey the directives of the state.

Principles of civil society, individuality, liberty are the features of the modern society, the very crux of modern life was framed along these lines - ironically - the modern state has become successful in containing them. The modern state has also been successful in moving carefully away from the law by locating loopholes along the way, individuality of an individual is lost with its privacy being attacked through these technologies of discipline and security enforced by the state, the individual is transformed into a state subject. The state needs to keep an eye on to maintain its hegemony over its subjects to protect the structures it has created. With the fear that if it fails to do so it won't be able to govern its subjects - to substantiate its survival and to eliminate every resistance it faces from the lower half of the spectrum that is the civil society. Since the surveillance of the subject is at an all-time high during the pandemic, it would not take much time for the state to ensure that this form of surveillance in becoming a norm to control the population and this form of surveillance with the aid of technology would not fail to disappoint it. 